\title{
Students' Perceptions: Using Writing Process Approach in EFL Writing Class
}

\author{
Utami Dewi ${ }^{1}$
}

DOI: 10.35445/alishlah.v13i2.555

\section{Article Info}

Keywords:

Perceptions;

Writing process;

WPA;

Writing class

Kata kunci:

Persepsi;

Writing process;

WPA;

Menulis

\section{Abstract}

The writing process approach (WPA) is a way to solve the problems of how the students express their ideas in producing essays systematically. The use of WPA needs to be examined from the students' perceptions because students' perception of the use of WPA influences students' writing ability. This study aims to investigate the students' perceptions on the application of WPA in EFL writing classes. This study applied a qualitative approach using a questionnaire and semi-structured interview with a written list of questions as a guide which focused on students' perceptions in the application of the WPA in their writing class. The data of the interview was analyzed by qualitative by using content analysis. The questionnaire results showed that most students had a highly positive and positive perception, while no students had a negative perception of the application of WPA based on the percentages. The results of interviews were concluded in four themes. Firstly, most students reported that they have highly positive opinions on WPA and considered the planning. Secondly, peer feedback is revising strategies as most useful. Thirdly, they stated that the steps in WPA were specific, systematic, and helpful. Lastly, they perceived that their writing product had improved after the application of WPA in writing class. The findings from the interviews corresponded with the findings from the questionnaire, which revealed that students had positive perceptions on the application of WPA in writing class; therefore, WPA can be suggested as the alternative approach to improve students' writing ability.

\begin{abstract}
Abstrak
Writing process approach (WPA) merupakan cara atau pendekatan untuk mengatasi masalah-masalah bagaimana mahasiswa- mahasiswa mengekspresikan ide-ide mereka dalam proses menulis essai secara sistematis. WPA tersebut perlu diuji dari sudut persepsi mahasiswa karena persepsi adalah factor penting lain dalam meningkatkan kemampuan mahasiswa. Penelitian ini bertujuan untuk mengetahui perspsi mahasiswa terhadap penggunaan WPA dalam kelas menulis Bahasa Inggris. Penelitian ini merupakan peneitian kualitatif dengan menggunakan angket dan interview yang menanyakan tentang persepsi mahasiswa terhadap pengaplikasian WPA dalam kelas writing mereka. Data interview dianalisa berdasarkan content analisis. Hasil dari angket menunjukkan bahwa kebanyakan mahasiswa memiliki persepsi sangat positif dan positif sementara tidak satupun mahasiswa memiliki persepsi negative terhadap penggunaan WPA dalam kelas menulis. Hasil dari interview disimpulkan menjadi tiga tema. Pertama, kebanyakan siswa melaporkan bahwa mereka memiliki persepsi positif yang sangat tinggi terhadap WPA dan mempertimbangkan planning sebagai tahapan yang paling berguna. Kedua, peer feedback merupakan strategi dalam merevisi yang sangat berguna. Ketiga, mereka menyatakan bahwa tahapan-
\end{abstract}

${ }^{1}$ Universitas Islam Negeri Sumatera Utara, Indonesia

Email: utamidewi@uinsu.ac.id 
tahapan dalam WPA sangat spesifik, sistematis, dan juga membantu. Keempat, mereka berpendapat bahwa hasil tulisan mereka meningkat menjadi lebih baik setelah penggunaan WPA dalam kelas menulis. Temuan pada interview sejalan dengan hasil dari angket yang menunjukan bahwa mahasiswa memiliki persepsi yang baik terhadap penggunaan WPA dalam kelas menulis. Sehingga, WPA dapat disarankan sebagai pendekatan yang dapat digunakan dalam meningkatkan kemampuan menulis mahasiswa.

\section{INTRODUCTION}

Writing is a complex skill that involves expressing ideas into sentences and paragraphs to communicate each piece of writing to the readers. In writing class, the students learned to express their ideas in the form of written language. In this study, the EFL writing class focused on improving the students' writing ability in English. Most of the students have problems expressing the ideas in a written foreign language, in this case, in English. Many factors influence the students' ability in EFL writing, such as the lack of students' ability to translate words in context, the common vocabulary, lack of the approaches, strategies, and techniques that the teacher and students used, the student's low motivation.

The teachers' teaching methodology and students' attitude and motivation affect the students' performance and ability. Appropriate instructional teaching methods and students' learning strategies enhance the students' achievement. Based on the observation, most students cannot write essays because they just focused on their writing product. The students never use any strategies or methods in writing an essay. They just wrote what they had in their mind in the form of written language. The students did not decide the topic before they write an essay, did not write an outline, did not revise their essay, did not edit and proofread before they published their essay. The students just focused on the writing product and never made the writing process approach in writing an essay.

Today, EFL writing class focuses on the product of writing and the process of writing. The writing process is essential in writing. It is not only the writing product as the central attention in EFL writing class. The process approach to the teaching of English Writing has been advocated in contrast with the traditional product-oriented method of teaching writing. It has been generally accepted and applied by English teachers in their classroom teaching of English writing. However, researchers occasionally have controversy concerning which approach is better, the process approach or the product method (Sun \& Feng, 2009). The process approach to writing can address some of the significant problems faced by the students and teachers (Al-sawalha, 2014). It was the reason for applying the writing process approach in EFL writing class as a systematic, specific approach that includes pre-writing, drafting, revising, and editing. Teaching writing as a process allows students to make suitable writing compositions because it includes several steps to identify their own mistakes and learn from them. The writing process should include pre-writing, drafting, editing, proofreading, evaluating, and publishing (Cando Guanoluisa, Campaña Pallasco, \& Panchi Herrera, 2017).

In EFL writing class, the writing process approach required much time to be done in EFL writing class. There are many stages, such as pre-writing, drafting, revising, editing and proofreading, and publishing. In the second semester, students of the English Department of the State Islamic University of North Sumatra studied intermediate writing subjects. In this subject, the teacher introduced the writing process approach (WPA) to the students in EFL writing class and trained them to use the WPA in the process of their EFL writing. WPA suggests providing teachers with strategies for promoting the generalization of writing skills in each stage of the writing process: pre-writing, drafting, revising, editing, and publishing. Firstly, pre-writing is the first step of the writing process as the guideline of writing. In this stage, the students do not start to write. They do their planning. They decide the topic and narrow the topic, consider the audience and purpose of the writing, and gather details before writing, such as outlining. Secondly, drafting means the students 
start to write the first draft of their writing. In this stage, the students need to focus on the word choice, grammar, and complex ideas that need to be developed in roughly the format they intend.

Thirdly, revising is correcting any significant errors such as revising the overall structure and sentences, revising word choice, and revising the paragraph to improve the writing. There are some revision strategies: color-coding and peer revision. Peer revision is used to give suggestions to get feedback from the peer as Dewi (2019) states that peer feedback is the comment or advice from equal partners, which can help the writer improve their product. Fourthly, editing and proofreading are when the writer polishes the writing and fix grammar, spelling, facts, and mechanics errors. Lastly, publishing is ready to share the product of the writing with the readers. Focusing on the necessary stages and phases of your writing and what happens to you at different parts of the process may provide you with essential learning milestones. You can benefit just as much as you can from a final, polished written product (Pritchard \& Honeycutt, 2005).

In intermediate writing class, each stage was done for one week. After following those five stages, the students' writing product has been improved. It can be seen from students' writing products after using the writing process. Those steps helped the students to have a better product of writing. It was seen from the students' essays before using and after using WPA in their EFL writing class. It showed that there was an improvement in students' ability to write an essay. Many pieces of research also discussed the implementation of WPA in improving students' writing ability. Implementing a process writing strategy using weblogs can improve the X MIA 3 students of Senior High School Lamongan's ability to write a descriptive text (Syarofi, Kuswahono, \& Rizky, 2018). This study described that the students prepared with the ideas to be developed and learned some vocabulary in the pre-writing stage. When the students revise and edit their drafts, they can recognize what should be added and omitted in their descriptive texts.

In addition, implementing the process approach in teaching writing can improve students" learning behavior and their ability to write narrative text (Gafur, 2020). The data of this study were obtained by writing tests and observation on the students' writing behavior and the researcher's performance in implementing the process approach in the classroom. This study showed that the average score of students' writing was improved from 62.81 in cycle I to 70.63 in cycle II. The students' writing skills can be enhanced, but it should follow the proper model procedures of the implementation of WPA developed (Miftah, 2015).

The writing process approach could increase the students' writing skills (Asriati \& Maharida, 2013). One approach that has significantly impacted second language writing is the process approach (Zen, 2005). Other research discussed the effect of the process writing approach on students' writing ability which was analyzed quantitatively (Imelda, Cahyono, \& Astuti, 2019). The research concluded that there was a significant effect of WPA on the students' writing ability.

Besides improving students' writing ability through WPA, the students' perception on the effectiveness of WPA was investigated as evaluation in this study to find out the students' voice and their experience in using the WPA in their EFL writing class. Students' perception affected the students' response, motivation, and attitude in the learning process. By the implementation of WPA, there was the result of students' writing product. Therefore, it was interesting to describe how the students' perception of the writing process in EFL writing class and which stage contributes to improving the students' writing product. Investigating the students' perception is one way to evaluate the usage of the method, techniques, or strategies in teaching learning process due to the perception describes their experience in applying those methods, techniques, or strategies. Rofiqoh \& Chakim (2020) stated that perception is how people select, organize, and interpret sensory stimuli to transform into meaningful information about their working environment. If the students' perception is positive, the acceptance of the approach is practical. On the other hand, if the students' perception is negative, the acceptance approach is constrained. It means that students' perception influences the success of using the approach applied by teachers or students. 
The perceptions of an individual eventually affect an individual's attitudes. In common, perception is described as a physical experience as a conscious feature of the world that demonstrates the capacity of a person to understand (Rofiqoh \& Chakim, 2020). Students have a particular perception of the strategies in learning writing, which can be either negative, positive, or highly positive; therefore, it influences their choices of the strategies used to improve their writing ability. In this study, the writing process approach (WPA) needs to be examined from the students' perceptions due to perception is another important factor in improving students' writing ability. This current study was qualitative, describing the students' perceptions of applying the writing process approach in EFL writing class. Previous research did not discuss which stages effectively affected the writing ability from the students' perspective. Therefore this study also focused on which stages gave contributions, mostly in students' writing essays.

\section{METHODS}

This study applied a qualitative approach in investigating the students' perception of using the writing process approach (WPA) in EFL writing classes. This study investigated the students' perception of the writing process approach applied in their EFL writing class. The subjects of this study were 45 students of the English Department of the State Islamic University of North Sumatra. Those students studied EFL writing class and applied WPA in writing their essays before collecting data. To find out the students' perception after the students applied the WPA in their writing class, the data were taken from the questionnaire and semi-structured interview with a written list of questions as a guide which focused on students' perceptions in the application of the WPA in their writing class. Firstly, the students were given a questionnaire of 20 numbers with a four-point Likert scale. All the questionnaires asked the students' perceptions about the application of WPA in their EFL writing class. Secondly, the semi-structured interview was used to search the students' perception in-depth about each stage of WPA. Only ten students were chosen to be interviewed, and the students were chosen randomly.

The questionnaire used the four-point Likert Scale. Therefore the total score of the questionnaires was 80. The questionnaires were calculated using highly positive, positive, and negative perceptions on WPA application in EFL writing classes. The questionnaires were also analyzed in each item to conclude. After analyzing the questionnaires, the interview data were analyzed to determine which stages of the writing process approach contributed to students' writing ability. In this study, the interview data were analyzed using content analysis to determine the messages' conclusion. The transcription was analyzed by finding the categories, then grouping the themes, and concluding. Krippendorff (in White \& Marsh, 2006) said content analysis is "a research technique for making replicable and valid inferences from texts (or other meaningful matter) to the contexts of their use." The notion of inference is fundamental in content analysis. The researcher uses analytical constructs, or rules of inference, to move from the text to the answers to the research questions. The two domains, the texts and the context, are logically independent, and the researcher concludes one independent domain (the texts) to the other (the context). In other words, content analysis involves coding, categorizing, and summarizing the content of the message.

\section{FINDINGS AND DISCUSSION}

\section{Students' Perception on WPA in EFL Writing Class}

The students' perception was investigated to know their experience, mental awareness, and social interaction using WPA in EFL writing class. The first finding was students' perception of WPA in EFL writing class which was analyzed from the data of the questionnaires. The number of items in the questionnaire was 20 with a four-point Likert scale. The highest score of the student questionnaire on the strategies in the writing process was 80 . The questionnaire was asked how the students did the writing process in writing an essay and their perceptions of using the writing process steps. 
The following table 1 represented the level of students' perception based on the scores of questionnaires. The level of perception was classified based on the scores of the student questionnaire. If the student's score was 70-80, the student's perception was highly positive. If the student's score was 51-69, it meant that students' perception was positive. If the student's score was 0-50, the student's perception was negative.

Table 1. The Scores of questionnaires and Level of students' Perception

\begin{tabular}{|c|c|c|c|}
\hline No. & Initial Name & Scores & $\begin{array}{c}\text { Level of } \\
\text { perception }\end{array}$ \\
\hline 1 & MR & 80 & Highly positive \\
\hline 2 & MZM & 79 & Highly positive \\
\hline 3 & WR & 80 & Highly positive \\
\hline 4 & HA & 69 & Positive \\
\hline 5 & MJ & 79 & Highly positive \\
\hline 6 & DA & 77 & Highly positive \\
\hline 7 & EPI & 80 & Highly positive \\
\hline 8 & $\mathrm{ZM}$ & 69 & Positive \\
\hline 9 & $\mathrm{AN}$ & 76 & Highly positive \\
\hline 10 & FA & 80 & Highly positive \\
\hline 11 & DLH & 79 & Highly positive \\
\hline 12 & $\mathrm{ZHD}$ & 68 & Positive \\
\hline 13 & RIW & 69 & Positive \\
\hline 14 & $\mathrm{AF}$ & 80 & Highly positive \\
\hline 15 & WP & 77 & Highly positive \\
\hline 16 & RW & 78 & Highly positive \\
\hline 17 & RAP & 69 & Positive \\
\hline 18 & $\mathrm{NH}$ & 79 & Highly positive \\
\hline 19 & $\mathrm{AH}$ & 68 & Positive \\
\hline 20 & NA & 80 & Highly positive \\
\hline 21 & $\mathrm{DK}$ & 68 & Positive \\
\hline 22 & $\mathrm{MF}$ & 78 & Highly positive \\
\hline 23 & IY & 73 & Highly positive \\
\hline 24 & $\mathrm{HU}$ & 79 & Highly positive \\
\hline 25 & NJ & 76 & Highly positive \\
\hline 26 & SA & 69 & Positive \\
\hline 27 & SM & 78 & Highly positive \\
\hline 28 & WA & 68 & Positive \\
\hline 29 & IS & 76 & Highly positive \\
\hline 30 & DR & 77 & Highly positive \\
\hline 31 & NM & 78 & Highly positive \\
\hline 32 & $\mathrm{AM}$ & 74 & Highly positive \\
\hline 33 & NS & 79 & Highly positive \\
\hline 34 & DK & 76 & Highly positive \\
\hline 35 & SY & 68 & Positive \\
\hline 36 & UA & 79 & Highly positive \\
\hline 37 & WH & 69 & Positive \\
\hline 38 & PS & 78 & Highly positive \\
\hline 39 & UH & 76 & Highly positive \\
\hline 40 & FA & 79 & Highly positive \\
\hline 41 & $\mathrm{BD}$ & 69 & Positive \\
\hline 42 & DI & 77 & Highly positive \\
\hline 43 & RV & 78 & Highly positive \\
\hline 44 & JF & 79 & Highly positive \\
\hline 45 & RA & 75 & Highly positive \\
\hline
\end{tabular}

Six students strongly agreed with all items of questionnaires. It was shown from the scores of the students was 8o. The result of the questionnaires illustrated students' perception of the application of WPA in EFL writing class as the table 2. 
Table 2. Students' scores of questionnaires

\begin{tabular}{lcc}
\hline Level of Perception & Scores & Number of students \\
\hline Highly positive & $70-80$ & 33 \\
Positive & $51-69$ & 12 \\
Negative & $0-50$ & 0 \\
\hline
\end{tabular}

The finding of students' perception based on the questionnaire were 33 students who have highly positive, and 12 students who have a positive perception of the application of the writing process in EFL writing class. Meanwhile, no one student has a negative perception.

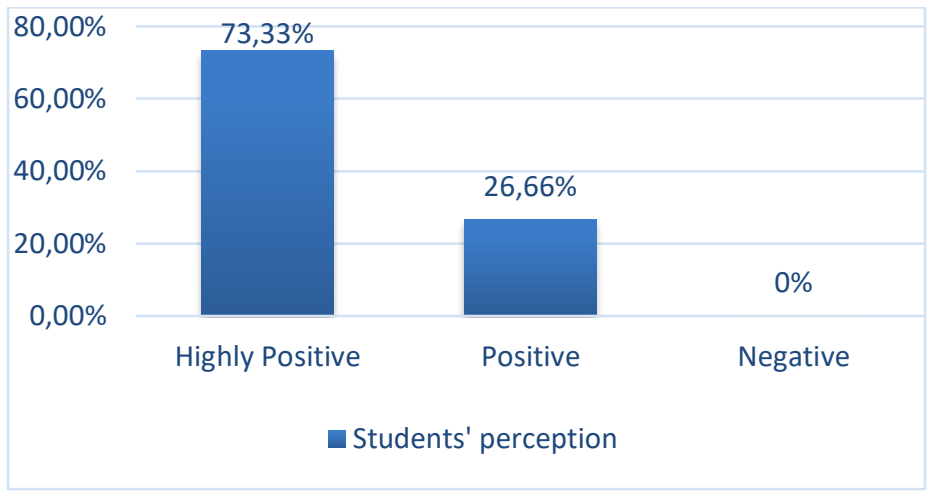

Figure 1. Percentages of students' perception

Based on the data above, the percentages of students' perceptions can be found, described in the following figure. Figure 1 showed that $73.33 \%$ were highly positive, $26.66 \%$ were positive, and $0 \%$ were negative. The finding of questionnaires showed that most of the students had a highly positive perception of WPA use, and some of them noticed a positive perception of the use of WPA in their writing class. On the other hand, no students had a negative perception of the application of WPA in EFL writing class. They assumed that the application of WPA helped them in improving their ability in EFL writing. It was concluded that the students' perception was highly optimistic on using the writing process to improve the essay. The finding of this study supported the other research. As Eliwarti \& Maarof (2017) also found in their study, a majority of the students had a Highly Positive level of perception of the strategies in the learning of EFL writing at $66.67 \%$. The remaining students indicated a Positive level of perception.

\section{Students' Perception on Stages of WPA in EFL Writing Class}

The questionnaires were analyzed from the students' answers in each item of the questionnaires to identify which stages of WPA help the students enhance their writing ability. The result below described the items which all students answered strongly agree with the statements in the questionnaires. All the students strongly agreed with questionnaires no. 1, 3, 4, and 5 . The results were described as the following.

Q1: The stages of the writing process help improve the writing ability.

From questionnaires number 1 (Q1), all students strongly agreed with the statement of the questionnaire. It was concluded that the students stated that each stage of the writing process improves the students' writing ability. This statement showed that the students had a positive perception of all stages of WPA.

Q3: Pre-writing is very helpful for you in improving the productivity of your writing.

The students claimed that the use of pre-writing was beneficial to improve their writing. It had been shown by the answer of questionnaire number 3 (Q3) that all of the students strongly agreed with the statement of questionnaires number 3. It meant that pre-writing had a good impact on students' writing essays. 
Q4: In my opinion, revising is one of the essential steps because the draft can be better.

Q5: After I have the first draft, I revise the draft by checking the sentences, paragraphs, and ideas.

This statement in questionnaires 4 (Q4) and no 5 (Q5) showed that all students also revealed that revising helped them increase their writing product.

From the items of questionnaires, all students agreed that the stages of WPA help the students in writing, especially pre-writing and revising. Both pre-writing and revising had a positive impact on students' writing. Pre-writing helps students to collect ideas, viewpoints, or ideas related to the topic being discussed. The revising stage focuses on providing the students chances to revise their first draft they had made in the drafting stage, emphasizing the content and organization rather than the mechanics (Miftah, 2015).

After getting the questionnaires' findings, the interview was used to find out the following information about students' perception of WPA in EFL class. The researcher interviewed ten students to probe their perception in depth. The interviews were semi-structured. The questions of interviews were:

1. Do you think that the writing process approach is useful to improve your writing product? Why?

2. Which stages of WPA help you to improve the writing product? What is your reason?

The content analysis of the interview transcription was used to analyze the transcription of the interview. The result of the content analysis is described in the following table 3. Firstly, identify the themes of each students' perception from the transcriptions of the interview. Secondly, cluster the themes categories.

\section{Table 3. Content Analysis of Interview}

\section{No Transcription of Interview \\ $1 \quad$ Yes, it is. In my opinion, all steps are beneficial because it makes me easy to write. \\ Peer feedback is helpful because my friend gives some suggestions to revise my draft and add the idea. (RIW) \\ Yes, the writing process is beneficial because it has five stages to follow. \\ Pre-writing is very helpful for me because before writing I know my topic and my purpose, and all steps are also helpful. (NH)}

The writing process is beneficial because of the many stages that help to write an essay.

Planning and revising are the most helpful for me because before this class, I never plan before writing, and I never revise after writing. I think that steps help me to improve my writing product. (AF)

Yes, the writing process makes me understand that writing is a process and has many steps to write better.

Revising is the most important because it gives feedback from my classmate. (WP)

Yes, it is because the steps are helpful. In pre-writing, I make the outline that is useful for the next step, which is drafting. (BD)

6 Yes, the writing process is helpful because it has five stages, from planning, drafting, revising, editing, and proofreading, and the number five, publishing. Revising was helpful to have better writing because we used peer feedback. (RA)

\section{Themes}

Peer feedback (revising), useful

(1)

Helpful, pre-writing, topic, and purpose

Helpful

Planning and revising, improve writing product.

Better writing

Revising, feedback

Pre-writing, useful, helpful

Revising, helpful feedback 
7

Yes, the writing process helps me improve my writing because it gives many steps to finish a piece of writing. I think revising is the most helpful because I get the feedback. (FA)

8

Yes, the writing process has specific steps and helps the writer.

All steps are helpful. (SY)

$9 \quad$ Yes, because the writing process is very systematic steps.

I think planning is the most useful because it is the clue of our writing. (MF)

$10 \quad$ Yes, the writing process is beneficial.

I am interested in all stages, but I think the most useful is revising because I can get suggestions and criticism from my classmate. (WH)
Improve my writing, revising, feedback

Specific steps, all steps, helpful

Systematic steps, planning

Helpful, revising, useful, suggestion and critics

The first content analysis was to find out the themes of the transcriptions of the interviews. The next was themes categories which were grouped from the themes in table 3. The themes categories were described to conclude which stages of WPA were the most valuable and helpful on students' EFL writing ability, as the table 4.

Table 4. Themes Categories

\begin{tabular}{lll}
\hline No & Themes & Categories \\
\hline 1 & $\begin{array}{l}\text { Helpful, pre-writing, topic, and purpose } \\
\text { Helpful, pre-writing and revising } \\
\text { Planning }\end{array}$ & $\begin{array}{l}\text { Planning is helpful to plan the } \\
\text { writing. }\end{array}$ \\
$2 \quad \begin{array}{l}\text { Peer feedback (revising), useful } \\
\text { Revising, feedback } \\
\text { Planning, useful, helpful } \\
\text { Revising, useful feedback } \\
\text { revising, feedback } \\
\text { Helpful, revising, useful, suggestion and critics }\end{array}$ & $\begin{array}{l}\text { Peer feedback is valuable and } \\
\text { helpful in revising. }\end{array}$ \\
2 & $\begin{array}{l}\text { Specific steps, all steps, helpful } \\
\text { Systematic steps }\end{array}$ & \\
3 & $\begin{array}{l}\text { Better writing } \\
\text { Improve my writing }\end{array}$ & $\begin{array}{l}\text { The steps in WPA were specific, } \\
\text { systematic, and helpful. }\end{array}$ \\
& & The writing product had \\
improved by the application of
\end{tabular}

After grouping the categories, the findings of the student's perception of the stages of WPA in their EFL writing class was concluded as the following:

1. Planning as the helpful stage to plan the writing

The students contended that planning was a valuable stage of WPA because, in the stage, the students decided the topic and purpose of writing. It was concluded from students' statements. For example, MH said: "Pre-writing is very helpful for me because I know my topic and my purpose before writing." In other words, pre-writing is the first stage of the writing process where the students did their planning. Pre-writing writing included choosing a topic, narrowing the topic, considering audience and purposes, and gathering details. The purpose of pre-writing is to take a chosen topic and gather thoughts involving that topic coherently (Asriati \& Maharida, 2013).

Other researchers also concluded that the process approach to writing could address some of the significant problems faced by the students and teachers. For instance, pre-writing activities' first component of process writing can help them overcome writer's block. The emphasis on expressing themselves at the drafting stage also helps them develop their ideas (Al-sawalha, 2014). As BD said 
that pre-writing is helpful to write the first draft (In pre-writing, I make the outline which is useful for the next step, that is drafting),

\section{Peer feedback as a useful and helpful strategy in revising}

Most students considered peer feedback as the most useful in revising. The third stage of WPA is revising. Most of the students made their revisions based on the peer feedback from their classmates in this stage. As RA said: "Revising was useful to have better writing because we used peer feedback." Kamberi (2013) stated that the study results have shown that feedback is an essential tool in learning and teaching a foreign language. From various feedback strategies used in the study, there were mixed perceptions of which strategy was the most effective in error correction from a learner's perspective.

Before revising the essay, the students can work together with classmates in giving suggestions, critics, or paise on their essay. After getting the peer feedback, they can sometimes add some ideas and change the sentences in revising the essay. It was some studies that discussed the effectiveness of peer feedback in revising students' writing. There was an improvement of students' scores before and after revision and students had a positive point of view toward implementing peerassessment in teaching writing (Mubarok, 2017). In addition, in his study, Leng ( 2014) described that the written feedback provided to the students was helpful and valuable in their essay revision.

\section{Writing process approach as systematic way and helpful}

The students said that the writing process as a systematic way contributes to enhancing their writing ability. Each stage of the writing process approach included pre-writing, drafting, revising, editing and proofreading, and publishing positively impact EFL writing ability. Teaching effective strategies at each stage of the writing process became an essential component of a writing class (Zen, 2005). Each stage has many strategies that help the students to have a better product of writing. SY said: "All steps are helpful." If the students follow this systematically, they will produce better writing. Therefore, the writing process is a specific, systematic way to help the students improve their writing. The process-based approach is beneficial to help the students generate their ideas and systematically organize them, which helps the students to write fluently (Agustiana, 2016).

\section{The improvement of students' writing product through WPA}

After they applied the WPA, the students were more aware of how they needed to plan before writing and revise the first draft to improve their product of writing. FA stated that the writing process helps me improve my writing because it gives many steps to finish a piece of writing. The students' statements showed that the application of WPA in EFL writing class improved the students' writing ability. The other research applied classroom action research, which concluded that implementing the writing process approach improved students' writing ability (Asriati \& Maharida, 2013; Miftah, 2015; Gafur, 2020; Syarofi, Kuswahono, \& Rizky, 2018).

\section{CONCLUSION}

The questionnaires represented that those students had a highly positive and positive perception of the writing process on their writing class. In contrast, no student has a negative perception. The students considered that the WPA was useful and helpful to improve their writing product, especially the step of pre-writing and revising. In conclusion, this study suggested WPA as the approach used in EFL writing classes by teachers and students. The highly positive perception on the use of writing process approach as the consideration to apply this approach in EFL writing class. Though, it needs to be researched further for more large numbers of students to get more detail of the students' perception and find out the advantages and disadvantages of WPA on EFL writing class. 


\section{REFERENCES}

Agustiana, V. (2016). Combining Product and Process-Based Approaches To Teaching Writing Discussion Texts. English Review: Journal of English Education, 4(2), 195. https://doi.org/10.25134/erjee.v4i2.334

Al-sawalha, A. M. (2014). Potential advantages of process writing for students English language and literature at Jerash University in Jordan. International Journal on Studies in English Language and Literature (IJSELL), 2(6), 41-46.

Asriati, S., \& Maharida, M. (2013). Improving the Students' Writing Skill By Using Process Writing Approach At the Second Grade Students of Smk Grafika Gowa Makassar. Exposure : Jurnal Pendidikan Bahasa Dan Sastra Inggris, 2(2), 224. https://doi.org/10.26618/ejpbi.v2i2.788

Cando Guanoluisa, F., Campaña Pallasco, G., \& Panchi Herrera, D. (2017). Students' perception about the writing instruction in English classes. Dominio de Las Ciencias, 3(4), 902-944.

Dewi, U. (2019). Peer Feedback in Reviewing Essay. SALTeL Journal (Southeast Asia Language Teaching and Learning), 2(2), 1-7. https://doi.org/10.35307/saltel.v2i2.26

Eliwarti, E., \& Maarof, N. (2017). The Students' Perceptions of the Strategies in the Process Approach. International Journal of Educational Best Practices, 1(1), 67. https://doi.org/10.31258/ijebp.v1n1.p67-82

Gafur, A. (2020). Implementing Process Approach to Improve the Ability of Writing Narrative Text of the First Semester Students Majoring Food and Beverage Study Program in Balikpapan State Polytechnic. JSHP : Jurnal Sosial Humaniora Dan Pendidikan, 4(2), 130-140. https://doi.org/10.32487/jshp.v4i2.878

Imelda, Cahyono, B. Y., \& Astuti, U. P. (2019). Effect of process writing approach combined with video-based mobile learning on Indonesian EFL learners' writing skill across creativity levels. International Journal of Instruction, 12(3), 325-340. https://doi.org/10.29333/iji.2019.12320a

Kamberi, L. (2013). The Significance of Teacher Feedback in EFL Writing for Tertiary Level Foreign Language Learners. Procedia - Social and Behavioral Sciences, 70(2008), 1686-1690. https://doi.org/10.1016/j.sbspro.2013.01.241

Leng, K. T. P. (2014). An Analysis of Written Feedback on ESL Students' Writing. Procedia - Social and Behavioral Sciences, 123(2000), 389-397. https://doi.org/10.1016/j.sbspro.2014.01.1437

Miftah, M. Z. (2015). Through Writing Process Approach. Journal of English as a Foreign Language, 5(1), 9-24. Retrieved from url: http://e-journal.iainpalangkaraya.ac.id/index.php/jefl\%oA

Mubarok, H. (2017). Students' Perception toward the Implementation of Peer-Assessment in Writing; Before and After Revision. Celt: A Journal of Culture, English Language Teaching \& Literature, 17(1), 13. https://doi.org/10.24167/celt.v17i1.1136

Pritchard, R. J., \& Honeycutt, R. L. (2005). Process Approach to Writing Instruction: Examining its Effectiveness. Handbook of Writing Research, pp. 275-290.

Rofiqoh, M., \& Chakim, N. (2020). Students' Perceptions on Written and Oral Feedback in Writing Class. Retain, 8(2), 57-65.

Sun, C., \& Feng, G. (2009). Process Approach to Teaching Writing Applied in Different Teaching Models. English Language Teaching, 2(1), 150-155. https://doi.org/10.5539/elt.v2n1p150

Syarofi, A., Kuswahono, D., \& Rizky, H. (2018). Implementing Process Writing Strategy Using Weblogs to Improve Students' Ability in Writing Descriptive Text. Lingua Cultura, 12(4), 351. https://doi.org/10.21512/lc.v12i4.4142

White, M. D., \& Marsh, E. E. (2006). Content analysis: A flexible methodology. Library Trends, 55(1), 22-45. https://doi.org/10.1353/lib.2006.0053

Zen, D. (2005). The Process Approach to ESL/EFL Writing a movement to process approach in esl writing. The Journal of Asia Tefl, 2(1), 191-198. 